The $3^{\text {rd }}$ Annual International Conference on Language and Literature (AICLL), 4-5 November 2020, Faculty of Literature, Universitas Islam Sumatera Utara (UISU), Medan, Indonesia

\title{
MORAL VALUES IN MARGONDANG OF ANGKOLA ETHNIC
}

\author{
Haksa Romatua Pohan, M. Manugeren, Purwarno Purwarno \\ Faculty of Literature \\ Universitas Islam Sumatera Utara, Medan \\ E-mail: haksapoi@gmail.com
}

\begin{abstract}
Margondang belonging to the ethnic of Angkola, becomes an important part of a celebration, especially in a wedding. Traditionally Angkola Ethnic Wedding can be said to be invalid if both families, either from the groom's family or the bride's do not carry out this Margondang tradition. At the very first glance Margondang is a traditional dance called a tortor having movements as a medium of communication on moral values, intended not only for the bride and groom to live together, but for all the guests and participants present to be more sensitive in carrying out life. Sensitivity here is certainly related to the harmonious relationship among humans and between humans with nature so that prosperous and peaceful life can be obtained. This is the core of the implementation of Margondang tradition. This study aims at analysing the moral values of Margondang, conducted by means of descriptive qualitative research method. Data collection procedures are supported by observation, interview and questionnaire techniques, covering 20 respondents chosen randomly in randomly-selected weddings in Medan. The results show that there are three points of moral value in Margondang: brotherhood, respect and responsibility.
\end{abstract}

Keywords: brotherhood, respect, responsibility

\section{Introduction}

Angkola ethnic is close to their tradition and they have a great respect on tradition. We desperately need our traditions. Part of the responsibility of having the chance to live at all, we should look at the tradition in a way that it is a part of the transmission of our particular family and ethnic customs. In so doing, we honor past generations by passing on their rites and rituals to the next generation. In this way, our family lineages stay stable and strong. Since ceremonies outlive us, they make us feel part of that larger sense of things as we pass them down to our own children, and theirs. That is how we realize our immortality, not in living forever, but in being part of living traditions. Our traditions act as a compass for all of our human relationships and personal interactions, the qualitative experiences of our family life, and ultimately, the development of civilized societies themselves. As we honor traditions, so we learn to honor ourselves, and in the final analysis, each other. Tradition is an examination of what we hold dear. When we come upon a tradition that someone practices and believes in wholeheartedly it can be inspiring. Though, it can also be quite scary. Of course, there are positive and negative traditions, and some have been set in motion, centuries old, and have brought this world enlightenment. But for a moment we will set aside the negative political, religious, and ancestral beliefs and focus on the bones of 
The $3^{\text {rd }}$ Annual International Conference on Language and Literature (AICLL), 4-5 November 2020, Faculty of Literature, Universitas Islam Sumatera Utara (UISU), Medan, Indonesia

what a positive family tradition brings to our life, what a tradition among friends can do for our soul, and how professional traditions can improve relationships and build our business.

Margondang is a traditional music of Angkola ethnic usually conducted in a wedding and this has become the pride of the ethnic. Margondang is also called "Horjia Godang" where there are several descriptions or series of other traditional events, the most popular activity known to the public in Margondang event is "Manortor", accompanied by gondang or Angkola traditional music, flute and paronang-onang (singer). Tortor is "dance with all the body moving with the guided gondang rhythm, with the center of movement in the hands and fingers, feet and soles of the feet, back and shoulders. " (Manalu, 2000: 215).

Margondang is also an expression of happiness for the marriage of children. Parents who love cultural customs in other words "par adat" feel uneasy if they do not "manggondangi" their children or do not carry out Marogondang events to celebrate their children's marriages. Margondang itself is carried out not only to celebrate weddings but also to express happiness for other purposes, such as the birth of a child, entering a new home, occupying a new position in someone else's career and others. As a legacy from the ancestors, the Margondang event is still being carried out in traditional Angkola events. Angkola is a Batak sub-tribe in the South Tapanuli area that does not know the administrative boundaries of the local government, so if called Batak Angkola, geographically bordered by:

- East side of North of Labuhan Batu and Riau Provinces.

- West side is bordered by Central Tapanuli.

- North side is bordered by North Tapanuli and Labuhan Batu.

- South side is bordered by the sea of Indonesia.

Seeing the boundaries as mentioned above means that Angkola is all over South Tapanuli Regency before it is divided. In terms of regional administration, the Angkola community mostly lives in the districts of North Padang Lawas Regency and Padang Lawas Regency, which were born in 2007 through Law No. 37 and 38 of 2007 (Kemenkumham : 2007). The population of the Angkola region consists of several clans, where the main clans are Harahap, Siregar, Pohan, Hasibuandan, Dasopang, Dalimunte and others.

\section{Literature Review}

Moral values are the standards of good and evil, which govern an individual's behavior and choices. Individual's morals may derive from society and government, religion, or self. When moral values derive from society and government they, of necessity, may change as the laws and morals of the society change. Morality describes the principles that govern our behavior. Without these principles in place, societies cannot survive for long. In today's world, morality is frequently thought of as belonging to a particular religious point of view, but by definition, we see that this is not the case. Everyone adheres to a moral doctrine of some kind. Morality impacts our everyday decisions, and those choices are directed by our conscience. Again, we must decide for ourselves where the conscience originates. Many people hold to the idea that the conscience is a matter of our hearts, that concepts of right, wrong, and fairness are "programmed" in each of us.

Poerdarminta (in Darmadi, 2006: 50) states that morals are teachings about the merits of actions and behavior. And Al-Ghazali says in (Ruslan, $2016: 70)$ that the moral term is "akhlaq". According to him: Morals are the behavior of the soul, without the need for thought and consideration. If the behavior is issued some good and commendable deeds, 
The $3^{\text {rd }}$ Annual International Conference on Language and Literature (AICLL), 4-5 November 2020, Faculty of Literature, Universitas Islam Sumatera Utara (UISU), Medan, Indonesia

both according to reason and religious guidance, the behavior is called good character. If the actions issued are bad, then the behavior is called bad character.

Sudarsono (1993: 159) defines morals as something related to norms of good / right and wrong behavior according to personal ethical beliefs or social rules, teachings about good deeds and behavior. Muhni (1994: 36-37) argues that morality is a phenomenon and at the same time an inherent social fact consisting of social rules and activities. In fulfilling his view of life, moral values need to be enshrined and instilled in every human soul so as to be in harmony. Moral prevailing in society is a demand for every individual in adjusting to their environment. Individuals who are considered to be able to meet the demands of society are individuals who not only think of satisfying their personal needs, but also pay attention to the interests of their community. This moral then becomes a guide for a person or group in regulating his behavior (Bertens, 1994: 3-8).

Lickona (2012) defines respect as an attitude of "showing regard for the worth of someone or something. It includes respect for self, respect for the rights and dignity of all persons, and respect for the environment that sustains all life. Respect is the restraining side of morality; it keeps us from hurting what we ought to value. The responsibility means the active side of morality which includes taking care of self and others fulfilling our obligations, contributing to our communities, alleviating suffering, and building a better world.

Responsibility and respect then lead to brotherhood. Brotherhood means the state of being a brother, and they always come first. Brotherhood makes you persevere and continue when times are tough. That specific time could be very simple or extremely problematic. The brotherhood has many meanings to it. Friendship, loyalty, security, love, and power, brotherhood is very important in life in general. It makes us successful in whatever we do. Something simple like a job interview, when the owner sees that you are very persistent in whatever you do he knows that you're dependable. We should note that brotherhood under discussion does not merely include those who share the same religion or belief. Rather, it implies boundless love that encompasses all people regardless of religion or belief and whether their attitude is hostile or not. The profundity and all inclusiveness of love indicated by universal brotherhood is grounded in the truth that God is the original Parent of all humanity. Another thing that should be noted is that this teaching brotherhood does not refer to some ideal or concept to be translated into reality through efforts.

\section{Research Method}

The research was conducted in Horja Godang's Hamdani Harahap in Medan, as one of a Angkola community leader in North Sumatera, surely this event was attended by Angkola people from various palaces especilly Medan. Data collection techniques are interviews, questionnaire documentation, and observation. The forms of the interview used are direct and unstructured interviews. The analytical approach in this study is data analysis interactive model suggested by Mile and Huberman (in Denzim and Lincoln, 1994). The respondents of 20 people are from various levels of society: academicians, religious leaders, societal leaders and young generations.

\section{Result and Discussion.}

Morals can be good or bad. In line with Algazali which means that if the behavior of the soul raises good morality then it is called good moral and if the result is bad behavior then it is called bad morality. Morals are related to norms or beliefs and teachings about goodness or deeds. Moral values need to be enshrined and instilled in every human soul so that they 
The $3^{\text {rd }}$ Annual International Conference on Language and Literature (AICLL), 4-5 November 2020, Faculty of Literature, Universitas Islam Sumatera Utara (UISU), Medan, Indonesia

become harmonious. In this study, there are three moral values to be analyzed in Margondang: brotherhood, respect and responsibility.

\subsection{Brotherhood}

After the data are collected, reduced and analyzed in accordance with the above theory, it can be concluded that the Host has previously fulfilled his wishes to large families including the "Dalihan na tolu" element, Mora: In-law of a daughter, Kahanggi: Surname brother, Anak Boru: son-in-law and his family (Parapat and Aritonang 2019: 7) conducted a Martahi (a family meeting) which was a deliberation to ask for the blessing and support of relatives about the intention of the Margondang event. The guests who will be invited to be made up of extended families have already written down the list, as proof that to carry out the Margodang event, the host always upholds a sense of brotherhood by involving the involvement of extended family both morally and materially, it is impossible for such a large event to be successful without support from extended families referred to in Batak custom terms including Angkola Dalihan Na Tolu namely Mora-Kahanggi-Anak Boru (Managor: 2013).

Silaturrahmi is also very useful for human life as social beings. In addition to creating a feeling of happiness for the host, it can also cause a feeling of happiness among the invited guests who attend the "Margondang" or "Horja Godang" event. What makes them proud of their ancestors who are so knowledgeable in the social sciences. They are social science experts that have not been matched until now. (Managor: 1995). because they have applied social science in social life for thousands of years that passed until now, it does not fade.

\subsection{Respect.}

Customary programs bind families together and upload a sense of necessity, solidarity and mutual respect both in joy and sorrow. (Siregar, 2006: 100). The Margondang event to celebrate the Angkola custom wedding is a joyous event, as a tribute to the guests who are welcome to take the dishes that are already available at the buffet table and then are always served food and soft drinks. Nice chairs are prepared for the guests. All the needs of guests are met as a courtesy; guests also show respect to the hosts and other fellow attendees by wearing good clothes.

\subsection{Responsibility.}

The concept of Dalihan Natolu conversion also conceptualizes a sense of responsibility. All positions contribute and are responsible for the tasks assigned to them; "Anak Boru"prepare all the needs of the event, starting from cooking foods and drinks, "galanggang" (location of manortor) chairs, aisle, to parking for vehicles of guests who will attend. A number of "Kahanggi" are responsible for the running of the Margondang event from the beginning to the end by asking for guidance and advice from the customary leaders who are expert in the Angkola custom. All the participants help one and another, showing sense of responsibility. "Mora" also solemnly follow the event processes from beginning to end with a full sense of responsibility. Mora's presence in the series of events is a contribution for the host in the success of the Margondang event.

\section{Conclusion}

After the records are collected and field checks are carried out by selecting and sorting data relevant to the research objectives, then presented by means of identification, 
The $3^{\text {rd }}$ Annual International Conference on Language and Literature (AICLL), 4-5 November 2020, Faculty of Literature, Universitas Islam Sumatera Utara (UISU), Medan, Indonesia

multiplication, systematic and comprehensive descriptions, it can be concluded that basically Margondang contains very high moral values, namely a sense of brotherhood, a sense of respect and sense of responsibility. The three moral values above are implanted in all people who participate in this Margondang event. Families who have not seen each other for a long time can stay in touch again, and tell each other about their situation. Mutual respect was evident in everyone who came to this Margondang event. The young respected the old, the men respected women and vice versa. Likewise with the sense of responsibility seen in the families involved in the preparation and implementation of this Margondang event, where everyone has their respective duties to make the Margondang event a success.

The Angkola ethnic communities are very proud of holding the margondang event, and believe Margondang will continue to be carried out by future generations. The traditional leaders interviewed during the research also really hope that Angkola ethnic everywhere can preserve and maintain the moral values contained in Margondang, especially for the younger generation.

\section{References}

Bertens. (1994). Etika. Jakarta: Gramedia Pustaka.

Darmadi, Hamid. (2012). Dasar konsep Pendidikan Moral. Bandung. Alfabeta.

Denzin, Norman K, Lincoln. dan Yvonna S. (1994). Handbook of Qualtative Research. Sage Publication-London.

Kementerian Hukum dan Hak Asasi Manusia Rapublik Indonesia. Undang-undang Republik Indonesia No. 37 dan 38 tahun 2007 tentang tentang Pembentukan Kabupaten.

Lickona, Thomas. (2012). Character Matters (Persoalan Karakter), Jakarta: Bumi Aksara, 258-259.

Managor, Sutan. (1995) Pastak-pastakni Paradaton, Medan : Media Medan.

Manalu, I. (1983). Mengenal Batak. Medan: Kiara.

Muhni, A. Imam, Djuretna. (1994).Moral dan Religi Menurut Emile Durkheim dan Henri Bergson.Yogjakarta: Kanisius

Parapat, Lili Herawatidan Aritonang, Devinna Riskiana. (2019). Buku Ajar Sastra dan Budaya Lokal untuk Perguruan Tinggi, Jawa Timur : Uwais Inspirasi Indonesia.

Ruslan, Rosma Elly, Nurul Aini. (2016). PENANAMAN NILAI-NILAI MORAL PADA SISWA DI SD NEGERI LAMPEUNEURUT, retrieved for https://media.neliti.com /media/publications /187368-ID-penanaman-nilai-nilai-moral-pada-siswa-d.pdf

Siregar, Amir Chatib. (2006). Surat Tumbaga Holing.Paper.

Sudarsono. (1993). Kamus Filsafat dan Psikologi, Jakarta: Rineka Cipta, 